\title{
Adult Choroid Plexus Neoplasm
}

National Cancer Institute

\section{Source}

National Cancer Institute. Adult Choroid Plexus Neoplasm. NCI Thesaurus. Code C8568.

A neoplasm of the choroid plexus occurring in adults. 